Original Article

\title{
PREVALENCE AND ANTIBIOTIC SUSCEPTIBILITY PATTERN OF HIGH LEVEL AMINOGLYCOSIDE RESISTANCE AMONG GRAM POSITIVE ORGANISMS IN A TERTIARY CARE CENTRE
}

\author{
DIVYA PRABHA A. ${ }^{*}$, POOJA NAIR ${ }^{2}$, S. S. M. UMAMAGESWARI ${ }^{3}$, R. MONICA ${ }^{4}$, ROSY VENNILA ${ }^{5}$
}

${ }^{1}$ Saveetha Medical College and Hospital, Thandalam, Chennai, ${ }^{2,3,4,5}$ Department of Microbiology, Saveetha Medical College and Hospital *Email: arukadp@gmail.com

Received: 13 Sep 2020, Revised and Accepted: 14 Nov 2020

\begin{abstract}
Objective: The study is done to determine the prevalence and the antimicrobial susceptibility against the gram positive organisms with high level amino glycosides resistance.
\end{abstract}

Methods: This is a prospective study involving the analysis of clinical samples for gram positive organisms like Streptococcus species, Enterococcus species and Staphylococcus species and determining their antimicrobial susceptibility pattern.

Results: From the collected clinical samples, all the gram positive organisms show resistance to gentamicin. Most of the Staphylococcus species showed a wide resistance to erythromycin followed by ceftrioxazone and many Enterococcus species shows resistance to penicillin, erythromycin, ciprofloxacin.

Conclusion: The high level aminoglycoside resistant (HLAR) gram positive organisms showed susceptibility to few drugs that are prevalent in various clinical samples. Surveillance of antimicrobial resistance and sensitivity is essential in managing and control of infection.

Keywords: Aminoglycoside, Staphylococcus, Enterococcus, Streptococcus, Antimicrobial susceptibility

(C) 2021 The Authors. Published by Innovare Academic Sciences Pvt Ltd. This is an open access article under the CC BY license (https://creativecommons.org/licenses/by/4.0/) DOI: https://dx.doi.org/10.22159/ijcpr.2021v13i1.40812. Journal homepage: https://innovareacademics.in/journals/index.php/ijcpr

\section{INTRODUCTION}

Aminoglycosides have been an important part of the antibiotics used since 1940s, which is obtained by screening of soil Actinomycetes for the elaboration of antimicrobial substance that yielded streptomycin [1]. Drugs that are classified under aminoglycosides are obtained from Streptomycesspp. (Drugs name ending with-mycin) neomycin, kanamycin, tobramycin or also derived from micromonosporaspp. (Drugs name ending with-micin) gentamicin, netilmicin, amikacin, sisomicin etc, Aminoglycosides exhibit concentration-dependent killing (CDK) and have prolonged post-antibiotic effects (PAE). That is on increasing the concentration of antibiotic, the rate of bactericidal action increases and on the other hand, on decreasing the concentration there is a persistent suppression of bacterial growth [2].

Aminoglycosides show their bactericidal activities against the aerobic organisms as they need oxygen for active transport through the inner membrane; therefore, these drugs are inactive against anaerobes. These acts by binding to the $30 \mathrm{~S}$ ribosome and freeze the initiation, interfere with the polysome formation and causes misreading of mRNA code [3]. They act against the gramnegative bacteria and the gram-positive organisms as well. Aminoglycosides along with penicillin, show a synergistic effect as the penicillin, being cell wall inhibitor, enhances the transport of aminoglycosides [4].

Acquired drug resistance in a bacteria may be due to single-step mutation (streptomycin etc.)) or multistep (erythromycin etc.)). The high-level resistance to gentamicin among the clinical isolates of Enterococcus faecalis was first reported in 1978 [5]. The transfer of resistance against aminoglycosides is through conjugation [6]. And the mechanism through which it develops is due to the formation of inactivating enzymes that acetylate, phosphorylate or adenylate the aminoglycoside and also through decreasing the drug permeability due to loss of specific channels [7]. The importance of these observations are based on the fact that high-level aminoglycoside resistance confabulates the resistance to bactericidal synergism between that aminoglycoside and cell wall active antibiotics $[6,8]$.

\section{MATERIALS AND METHODS}

Isolation and identification

Gram-positive organisms were isolated from various clinical samples from both in-patients and out-patients over a period of five months from January to May 2020 in the clinical laboratory of microbiology department, Saveetha Medical College and Hospital, Thandalam, Tamil Nadu. The samples from which the bacterial species isolated were exudates, urine, blood and respiratory samples and a routine Gram Staining was done. From these, the samples were inoculated on to blood agar and McConkey agar (without Crystal Violet) [9]. The isolates were identified based on their reactivity on the cultures, shape on gram staining, motility test and other required biochemical reactions. These include bile soluble test, bile esculin test, pigment production, heat tolerance test, mannitol fermentation test, catalase test, coagulase test, bacitracin testing etc. The study was approved by the Institutional Review Board.

\section{Antimicrobial susceptibility testing}

Kirby Bauer disk diffusion method was used to perform the antimicrobial susceptibility test as recommended by the National Committee for Clinical Laboratory Standards (NCCLS, 2002) [10]. Individual isolates were inoculated on Mueller Hinton Agar plates at a concentration of $10^{6}$ Colony Forming Units (CFU) by lawn culture method [11, 12]. Discs impregnated with antibiotics Ampicillin (10mcg), Ceftriaxone (30 mcg), Cefoxitin (30mcg), Cotrimoxazole (25mcg), Ciprofloxacin (5mcg), Erythromycin (15mcg), Linezolid (30mcg), Norfloxacin (30mcg), Nitrofurantoin (300mcg), Penicillin (10mcg), Tetracycline (10mcg), Vancomycin (30 mcg), High Level Gentamicin $(120 \mathrm{mcg})$ were placed. Plates were examined after $24 \mathrm{~h}$ of incubation at $37^{\circ} \mathrm{C}$.

\section{RESULTS}

In this study, a total of 97 clinically relevant gram-positive cocci were identified. Colony characteristics on the agar plates and the 
reactions observed from the biochemical tests performed for each isolates were noted [table 1]. The most prevalent gram-positive cocci isolated were Staphylococcus species followed by Enterococcus species and Streptococcus species.

Table 1: Colony characteristics and general biochemical test reactions used for the isolates

\begin{tabular}{|c|c|c|c|c|c|}
\hline \multicolumn{2}{|c|}{ Staphylococcus species } & \multicolumn{2}{|c|}{ Streptococcus species } & \multicolumn{2}{|c|}{ Enterococcus species } \\
\hline Gram staining & Gram-positive cocci in clusters & $\begin{array}{l}\text { Gram } \\
\text { staining }\end{array}$ & $\begin{array}{l}\text { Gram-positive cocci in chains } \\
\text { and pairs }\end{array}$ & Gram staining & $\begin{array}{l}\text { Gram-positive cocci } \\
\text { in short chains }\end{array}$ \\
\hline $\begin{array}{l}\text { On Blood } \\
\text { Agar }\end{array}$ & $\begin{array}{l}\text { Colonies with narrow zones of } \\
\text { beta haemolysis }\end{array}$ & $\begin{array}{l}\text { On Blood } \\
\text { Agar }\end{array}$ & $\begin{array}{l}\text { Pin point colony with wide zone } \\
\text { of beta hemolysis ( } S \text {. pyogenes) } \\
\text { or alpha hemolysis (S. viridians) }\end{array}$ & On Blood Agar & $\begin{array}{l}\text { Translucent colonies } \\
\text { of non-hemolytic type }\end{array}$ \\
\hline $\begin{array}{l}\text { On Mac } \\
\text { conkey agar }\end{array}$ & $\begin{array}{l}\text { Pink colonies due to lactose } \\
\text { fermentation }\end{array}$ & $\begin{array}{l}\text { On Liquid } \\
\text { Medium }\end{array}$ & $\begin{array}{l}\text { Granular turbidity with } \\
\text { powdery deposit }\end{array}$ & $\begin{array}{l}\text { On Mac } \\
\text { Conkey Agar }\end{array}$ & $\begin{array}{l}\text { Magenta pink } \\
\text { colonies }\end{array}$ \\
\hline Catalase & Bubbles appearance & $\begin{array}{l}\text { Bacitracin } \\
\text { sensitivity }\end{array}$ & $\begin{array}{l}\text { Presence of zone of inhibition } \\
\text { (S. pyogenes) }\end{array}$ & $\begin{array}{l}\text { Bile Esculin } \\
\text { test }\end{array}$ & $\begin{array}{l}\text { Black colour in the } \\
\text { medium }\end{array}$ \\
\hline $\begin{array}{l}\text { Slide } \\
\text { coagulase }\end{array}$ & $\begin{array}{l}\text { Positive-Coarse clumps formed } \\
\text { (Staphylococcus aureus) } \\
\text { Negative-no clumps (Coagulase } \\
\text { negative Staphylococcus) }\end{array}$ & $\begin{array}{l}\text { Optochin } \\
\text { sensitivity }\end{array}$ & $\begin{array}{l}\text { Presence of zone of inhibition } \\
\text { (S. pneumoniae) }\end{array}$ & $6.5 \% \mathrm{NaCl}$ & Growth is seen \\
\hline $\begin{array}{l}\text { Tube } \\
\text { coagulase }\end{array}$ & Clot formation is seen. & & & & \\
\hline
\end{tabular}

The distribution of clinical samples, which includes blood, exudates, urine and respiratory samples from which these gram-positive cocci were isolated is given in table 2 .

Table 2: Distribution of various specimen type among the gram-positive bacteria

\begin{tabular}{|c|c|c|c|c|}
\hline \multirow[t]{2}{*}{ Specimen type } & \multicolumn{4}{|l|}{ Number of isolates } \\
\hline & Staphylococcal species & Streptococcal species & Enterococcal species & Total \\
\hline Blood & 20 & 1 & 2 & 23 \\
\hline Exudates & 26 & 1 & 1 & 28 \\
\hline Urine & 16 & - & 24 & 40 \\
\hline Respiratory samples & 6 & - & - & 06 \\
\hline Total & $68(70.1 \%)$ & $2(2.1 \%)$ & $27(27.8 \%)$ & 97 \\
\hline
\end{tabular}

Out of 97 clinical specimens, 71 were from in-patient (IP) samples and 26 were from out-patients (OP).

From table 2 and 3, it is interpreted that high-level aminoglycoside resistant gram-positive organisms like Staphylococcal species, which includes MRSA and CoNS were predominant in blood, exudate and in respiratory samples and least in the urine sample and accounts for $70.1 \%$ of total clinical isolates whereas Enterococcal species were predominant in the urine sample as compared with the blood and exudate and it accounts for $27.8 \%$ of the total clinical samples. Streptococcal species were the least of all and accounts for $2.1 \%$ of total clinical isolates.

All the 27 Enterococcal spp and 2 Streptococcus spp showed High level Gentamicin resistance, whereas 56 out of 68 Staphylococcus spp showed resistance to HLG.

The susceptibility of the high-level aminoglycosides resistant (HLAR) bacteria against various other antibiotics was also obtained through disk diffusion method, interpreted and shown in table 3 .
The susceptibility test is conducted against various antibiotics out of which HLAR organisms showed maximum resistance to erythromycin (68\%) and ceftriaxone (66\%) among Staphylococcus species and to ampicillin (56\%) and penicillin (56\%) among Enterococcal species (table 3). The Streptococcal species were resistant to the antibiotics like ampicillin, erythromycin, penicillin, cotrimoxazole and Enterococcal spp showed resistance towards ampicillin, few cephlosporins, norfloxacin, penicillin, tetracycline whereas, the Staphylococcus shows resistance to almost all of them. There was a notable range of cefoxitin resistance among the HLAR staphylococcus species that can be either Methicillin-Resistant Staphylococcus aureus (MRSA) or Methicillin Resistant Coagulase negative Staphylococcus spp. (MR CoNS).

There were 12 Staphylococcus species which were found out to be susceptible for High-level Gentamicin. All these 12 isolates were susceptible to vancomycin, linezolid, cotrimoxazole and ceftriaxone.

Table 3: Antimicrobial susceptibility pattern of HLAR gram-positive bacteria

\begin{tabular}{|c|c|c|c|}
\hline Antibiotics used & Staphylococcal species & Streptococcal species & Enterococcal species \\
\hline Ampicillin & $11(20 \%)$ & $1(50 \%)$ & $15(56 \%)$ \\
\hline Ceftriaxone & $37(66 \%)$ & - & $3(11 \%)$ \\
\hline Cefoxitin & $24(43 \%)$ & - & - \\
\hline Ciprofloxacin & $12(21 \%)$ & - & $13(48 \%)$ \\
\hline Cotrimoxazole & $28(50 \%)$ & $1(50 \%)$ & $7(26 \%)$ \\
\hline Erythromycin & $38(68 \%)$ & $1(50 \%)$ & $13(48 \%)$ \\
\hline Linezolid & $2(4 \%)$ & - & - \\
\hline Norfloxacin & $5(9 \%)$ & - & $3(11 \%)$ \\
\hline Nitrofurantoin & $2(4 \%)$ & - & $7(26 \%)$ \\
\hline Penicillin & $9(16 \%)$ & $1(50 \%)$ & $15(56 \%)$ \\
\hline Tetracycline & $6(11 \%)$ & - & $2(7 \%)$ \\
\hline Vancomycin & $2(4 \%)$ & - & $12(44 \%)$ \\
\hline
\end{tabular}

From table 3, we were able to interpret that most of the HLAR Staphylococcus spp showed sensitivity for penicillin, linezolid, tetracycline and vancomycin. On the contrary, the majority of the HLAR Enterococcal spp exhibited resistance to vancomycin, amplicillin and penicillin. 


\section{DISCUSSION}

Over the last few years, we have witnessed different kinds of drug resistance emerging from various bacterias. The present study demonstrates the prevalence and antimicrobial susceptibility pattern of HLG resistance gram-positive organisms like Streptococcus spp, Enterococcus spp, Staphylococcus spp against various antibiotics. In our study, out of the total 97 isolates, the majority $(73 \%)$ were recovered from hospitalized patients than the outpatients, similar to other studies [11].

Within the HLAR Staphylococcal isolates, higher resistance were towards erythromycin (68\%), ceftriaxone (66\%) and cotrimoxazole (50\%), while it was more sensitive towards linezolid and vancomycin (96\%) followed by penicillin (84\%). Habeeb Khadri et al.[9] have shown a similar result with Staphylococcus spp ie., have shown resistance for cotrimoxazole but also shows more resistance for penicillin than our study and less percentage for vancomycin. From Mohanty S et al.[10], it was in accordance to our study that most of the enterococcus spp were resistance to penicillin, ciprofloxacin, erythramycin. According to our study, Enterococcus showed resistance to ampicillin too.

\section{CONCLUSION}

From this study, it is concluded that the HLG resistant grampositive organisms are acquiring resistance to various other antibiotics too and is still sensitive to some, which varies with different bacteria. This study emphasizes the need for HLAR screening in patients suffering from various infections. Routine HLAR screening can help the clinicians in limiting the spread of resistance.

\section{FUNDING}

Nil

\section{AUTHORS CONTRIBUTIONS}

All the authors have contributed equally.

\section{CONFLICT OF INTERESTS}

Declared none

\section{REFERENCES}

1. Mandell, Douglas, Bennett. Principal and practice of infectious disease (eighth edition. Vol 1); 2015. p. 235-51.

2. Vogelman BS, Craig WA. Postantibiotic effects. J Antimicrob Chemother 1985;15 Suppl A:37-46.

3. Davis BD. Mechanism of bactericidal action of aminoglycosides. Microbiol Rev 1987;51:341-50.

4. Indrelie JA, Wilson WR, Matsumoto JY, Geraci JE, Washington JA. $2^{\text {nd. }}$ Synergy of imipenem or penicillin $\mathrm{G}$ and aminoglycosides against enterococci isolated from patients with infective endocarditis. Antimicrob Agents Chemother 1984;26:909-12.

5. Horodniceanu T, L Bougueleret, N El-solh, G Bieth, F Delbos. High level, plasmid-borne resistance to gentamicin in streptococcus faecalis subsp. Zymogenes Antimicrob Agents Chemother 1979;16:686-9.

6. Eliopoulos GM, Wennersten C, Zighelboim Daum S, Reiszner E, Goldmann D, Moellering RC Jr. High-level resistance to gentamicin in clinical isolates of streptococcus (Enterococcus) faecium. Antimicrob Agents Chemother 1988;32:1528-32.

7. Courvalin P, Davies J. Plasmid-medicated aminoglycoside phosphotransferase of broad substrate range that phosphorylates amikacin. Antimicrob Agents Chemother 1977;11:619-24.

8. Mederski Samoraj BD, BE Murray. High-level resistance to gentamicin in clinical isolates of enterococci. J Infect Dis 1983;147:751-7.

9. Habeeb Khadri, Mohammad Alzohairy. Prevalence and antibiotic susceptibility pattern of methicillin-resistant and coagulase-negative staphylococci in a tertiary care hospital in india. Int J Med Med Sci 2010;2:116-20.

10. Mohanty S, Jose S, Singhal R, Sood S, Dhawan B, Das BK, et al. Species prevalence and antimicrobial susceptibility of enterococci isolated in a tertiary care hospital of North India. Southeast Asian J Trop Med Public Health 2005;36:962-5.

11. Jain S, Kumar A, Kashyap B, Kaur IR. Clinico-epidemiological profile and high-level aminoglycoside resistance in enterococcal septicemia from a tertiary care hospital in east Delhi. Int J Appl Basic Med Res 2011;1:80-3.

12. Forbes BA, Sahm DF, Weissfeld AS. editors. Approaches to diagnosis of infectious diseases and evaluation of an antimicrobial activity. 12 ed. Washington DC: Mosby Elsevier. Diagnostic Microbiology; 2007. p. 78-215. 